\title{
The Non-Linear Relation between Governance and Efficiency: Evidence from Agriculture
}

\author{
Nizamettin Bayyurt ${ }^{1 *}$, Zehra Vildan Serin ${ }^{2}$
}

${ }^{I}$ Department of Industrial Engineering, Faculty of Management, Istanbul Technical University, 34367Maçka/İstanbul, Turkey

${ }^{2}$ Department of Economics, Faculty of Economics, Administrative \& Social sciences, Hasan Kalyoncu University, 27410 Sahinbey/Gaziantep, Turkey

A R T I C LE INFO

\section{Research Article}

Received 31 July 2017

Accepted 04 October 2017

Keywords:

Agricultural efficiency

Governance

Data envelope analysis

Efficiency

Nonlinear

\begin{abstract}
A B S T R A C T
This study aims to explore the relations between governance and agricultural performance of countries. Data Envelopment Analysis was used to find out agricultural performance of 81 countries at first stage. Panel data regression was employed in the second stage to assess the relations between performance levels of countries and their governance. Six governance indicators namely; voice and accountability, control of corruption, government effectiveness, regulatory quality, rule of law and political stability and violence were analyzed in this stage. Findings show that firstly, governance indicators are highly correlated with each other. Secondly, developed countries are more efficient and have better governance than developing and undeveloped countries. Finally, a quadratic form of regression was the fitting model that is the marginal effects of good governance on performance are increasing in high values of governance.
\end{abstract}

\footnotetext{
*Corresponding Author:

E-mail: bayyurt@itu.edu.tr

DOI: https://doi.org/10.24925/turjaf.v5i11.1334-1341.1454
}

\section{Introduction}

As a principle source of food and livelihood, agricultural sector is important at both national and international level. Food insecurity has become a serious concern especially in sub-Saharan Africa Otsuka (2013). One in nine people on earth do not have enough food and majority of the world's hungry people live in developing countries especially in Asia continent (WFP, 2014). Hence, improvement in agricultural efficiency is one of the most significant problems for all of the world economies. Many researchers and policy makers have paid particular attention in analysis of agricultural productivity (Ogundari et al., 2012; Otsuka, 2013; Thiam et al., 2001).

The position of government in the agricultural markets is always attracted the mind of politicians and economists. Since Roman Empire many researchers have developed new theories for solving agricultural inefficiencies and they have discussed the relationship between government and markets. Agricultural sector that has specific features differs from the other sectors. Firstly, agriculture is dependent on climatic conditions, therefore it is seen the volatility in both agricultural price and agricultural supply. Secondly, technological developments can lead to falling farmers' income rather than rising incomes.
Thirdly, intensive farming causes the environmental costs and negative externalities due to excessive using artificial fertilizers. Finally, there are positive externalities on the rural life, and then governments generally subsidize farmers to protect the rural communities. All of them create imperfections in information, limitations in competition, and incomplete markets that are the main source of chronic inefficiencies (Stiglitz, 2008).

From the Great Depression until the late 1970s, Keynesian Economists and policy makers believed the importance of the government interventions for correcting the market failures. This approach changed with Washington Consensus which was started in late 1970s and continued until 1990s. In this period, there was a strong belief in the power of three big ideas: market economy, openness to the world, and macroeconomic discipline. Instead of government intervention, there was a trust to the market fundamentals which would bring the best results for the efficiency. In the first period of Post Washington Consensus it was argued that "small government" would be more effective to solve market failures (Graham et al., 2003). Since the 1990s, researchers and practitioners have focused on "good governance" as both a means of achieving development 
and a development objective in itself. The World Bank has defined "good governance" as "epitomized by predictable, open and illuminated policies; a bureaucracy working with a professional ethos; a government accountable for its actions; and a strong civil society participating in public affairs; and all acting under the rule of law" (Worldbank, 1994). According to IFPRI (2014) "governance is the exercise of economic, political and administrative authority to manage a country's affairs at all levels". So, governance has impact on policies, investment, production, employment, literacy and other essential elements of the whole system.

There are huge gaps between per capita incomes of the world economies due to their both differences between productive resources, public policies and institutions (Olson, 1996). "Good governance is perhaps the single most important factor in eradicating poverty and promoting development" (IFPRI, 2014). If good governance is the key of sustainability and reducing poverty, then what is good governance and how can a relationship be constructed between good governance and agriculture? This paper aims to explore the governance indicators and the relations between governance and agricultural performance. Remaining sections of the paper are organized as follows: The next section is devoted to literature review. After this section, the third section explains the methodologies which are employed in the study. Following to this section, the fourth section explains the results of the analyses. Finally, the paper ends with the final section conclusions and discussion.

\section{Literature Review}

For almost last two decades' governance has been examining with different variables across different regions like governance and economic growth (RiveraBatiz, 2002; Zubair and Khan, 2014), or governance and foreign direct investment (Globerman et al., 2004; Subasat and Bellos, 2013). Recently, the relationship between good governance and agricultural productivity has received attention among scholars (Lio and Liu, 2008; Bayyurt and Yilmaz, 2012; Fuglie and Wang, 2013; Siudek and Zawojska, 2014 ).

Kaufmann et al. (2006a) improved governance indicators which are voice and accountability, political stability and violence, government effectiveness, regulatory quality, rule of law, control of corruption in order to measure quality of the governance or in other words to measure the trustability of the system. Many researchers have used these indicators to explore the relationship between governance and economic performance. Kaufmann et al. (2006b) have developed a function consisting of governance variables to explain efficiency differences in agricultural between countries. The representative variables, that symbolized governance infrastructure, were developed in this study of Kaufmann that was covering the years of 1996, 1998, 2000 and 2001.

Thomas (2008) and Feng (2003) found a significant link between institutions' quality of governance, the political regime and economic growth. Campos, Lien and Pradhan (1999) and Lio and Liu (2008) investigated the impacts of good governance on agricultural productivity. Meidari (2004) showed that the specific place of institutionalization of civil society in the developing countries. Beckmann and Boger (2004) investigated 306 Polish farmers in 1999. They analyzed the effects of contract enforcement in transition agriculture. Investigating 62 countries Méon and Weill (2005) found that only government effectiveness has a significant relation with governance while political stability, control of corruption and quality of regulations are not. Azmat and Coghil (2008) evaluated the market based reforms in Bangladesh, and they concluded that agricultural inputs were most effective on the improvement on food security. Olson (1996) argued that the lack of specialization and adequate institutional framework caused wasting money and resources in poor countries. Zerfu (2007) found that confidence government and officials index, strengthening property rights and communication with local governments were the most effective indicators in Ethiopia. Bayyurt and Yilmaz (2012) examined the effects of education and the governance on agricultural efficiency for 64 countries. They found that education, country type and the index of legislature quality have impacted on efficiency. Subash and Roy (2011) focused on the impacts of good governance on small farm's system in Asia and Oceania. Fuglie and Wang (2013) showed that agricultural efficiency of developed countries was higher than developing countries. Beckmann and Boger (2004) analyzed the effects of contract enforcement in transition agriculture. Pender and Fafchamps (2001) found that higher education to be associated with lower intensity of labor use. Nguyen and Giang (2008) analyzed the technical efficiency in Vietnam agriculture between the years 1990 and 2005. Serrao (2003) investigated the agricultural productivity in EU countries for the period of 1980-1998 and found good performances for Germany, Belgium and Luxembourg. Several studies (Knack and Keefers (1997), International Fund for Agricultural Development (IFAD) in Italy (1999), Knack (2003), Feng (2003), and Niyongabo (2003) have examined the interdependence of good governance and economic growth.

In the Turkish agricultural literature there aren't much studies related with efficiency and governance. Deliktaş et al. (2005) examined the relative efficiencies and total factor productivity indexes of agriculture industries of Turkey and 14 EU countries for the period 1980-2002 using Data Envelopment Analysis (DEA). They observed advancement in technology and a decline in efficiency. Kaya and Avcr (2008) examined the agricultural productivity in 24 transition economies including Turkey for the period between 1994 and 2004. In their study, while Turkey's value of change in technical efficiency remained the same as the average of other countries, its value of technological change lagged behind others. Turkey's total factor productivity was also lower than the average of the other countries. Çakmak (2008) investigated the changes in efficiency of the agriculture 
sector on the basis of the regions of Turkey. Bayyurt and Yilmaz (2012) analyzed the impacts of governance and education on agricultural efficiency in a global context including Turkey between 1993 and 2006 and they found that regulatory quality has a positive effect on agricultural efficiency. Another study conducted by Bayyurt et.al (2015) using 24 EU countries including Turkey found the impacts of voice and accountability, the share of R\&D in GDP and the share of food products in exports upon the agricultural efficiency as positive whereas the impact of the share of GDP allocated to education upon agricultural efficiency as negative.

Massuanganhe (2008) states that poor governance and weak institutional capacity will be the result of poor policies which is incapable with addressing the challenges of agriculture and rural development, also it creates inefficient markets, unemployment, problems in the flow of aid to agricultural and rural development.

It is expected that good governance should increase agricultural efficiency. It is responsive the needs of the entire community interests. It is equitable and inclusive. All groups in society have opportunities to participate in the process. Accountability brings an obligation to local governments for the results of decisions. The rule of law provides the consistency of decisions with relevant legislation or common law. Transparency provides symmetric information to farmers.

Hence, to test the relations between governance and efficiency, data of 81 countries for the period of 2002 2012 were collected from World Bank data base. The sample consists of the data of 34 high incomes, 27 uppermiddle incomes, and 20 lower-middle and low incomes countries (classification is according to the description of the World Bank).

\section{Methodology}

The main goal of the study is to explore the relations between countries' agricultural efficiency and their governance. For the measurement of agricultural efficiency Data Envelopment Analysis (DEA) was employed.

DEA is a nonparametric method which is based on linear programming and aims to measure the relative efficiencies of Decision-making Units (DMUs) based on one or more input and output values (Charnes et al., 1994). In the case of one input and one output, ratio analysis can be used to compare DMUs. However, when the number of inputs and outputs are more than one, or when the inputs and outputs are in different scales, the ratio analysis cannot be applied. DEA allows multiple inputs and multiple outputs to be evaluated together even in different scales. In DEA, units are compared to the most efficient units, not to means.

The general formulation of DEA model can be illustrated as follows:

$$
\text { Efficiency }=\frac{\text { Weighted sum of outputs }}{\text { Weighted sum of inputs }}
$$

Suppose that "n" number of units have "m" number of inputs and "s" number of outputs. The efficiency of p-th unit can be calculated as follows, based on what Charnes et al. (1978) suggest:

$$
\begin{aligned}
& \operatorname{Max} \sum_{k=1}^{s} v_{k} y_{k p} / \sum_{j=1}^{m} u_{j} x_{j p} \\
& \sum_{k=1}^{s} v_{k} y_{k i} / \sum_{j=1}^{m} u_{k} x_{j i} \leq 1 ; \quad \forall i \\
& v_{k}, u_{j} \geq 0 ; \quad \forall k, j \\
& \mathrm{k}=1 \ldots \mathrm{s}, \mathrm{j}=1 \ldots \mathrm{m}, \mathrm{i}=1 \ldots \mathrm{n}, y_{k i}=\text { amount of k-th }
\end{aligned}
$$
output yielded by $\mathrm{i}$-th unit, $x_{j i}=$ amount of $\mathrm{j}$-th input used by $\mathrm{i}$-th unit, $v_{k}=$ weight of $\mathrm{k}$-th output, $u_{j}=$ weight of $\mathrm{j}$ th input.

Objective function is the maximization of the ratio of weighted outputs to weighted inputs. Constraints, on the other hand, is for the ratio of weighted outputs to weighted inputs to be less than or equal to 1 . The objective function and constraint given above is converted into the linear programming form. The converted linear programming model is written for each DMU separately and is run $\mathrm{n}$ times. The result obtained for each unit is its efficiency score. In order to maximize the efficiency of each unit, amounts of inputs and outputs are weighted properly. The envelopment surface will differ on the scale assumptions that describe the model. Two scale assumptions are generally employed: constant returns to scale (CRS), and variable returns to scale (VRS). The CRS reflects the fact that output will change by the same proportion as inputs are changed eg; doubling of all inputs will double output (Bayyurt and Yilmaz, 2012). In this study we use CRS model

An output oriented CRS DEA model in the literature, can be expressed below for $m$ inputs, $s$ outputs and $n$ DMUs:

$$
\begin{aligned}
& \operatorname{Max} \theta_{k}=\phi_{k}+\varepsilon\left(\sum_{i=1}^{m} s_{i}{ }^{-}+\sum_{i=1}^{s} s_{r}^{+}\right) \\
& \text {s.t } \\
& y_{r k} \phi_{k}-\sum_{j=1}^{n} y_{r j} \lambda_{j}+s_{r}^{+}=0, \quad j=1, \ldots, n \\
& x_{i k}-\sum_{j=1}^{n} x_{i j} \lambda_{j}-s_{i}^{-}=0, \quad i=1, \ldots, m \\
& \lambda_{j}, s_{i}^{-}, s_{r}^{+} \geq 0 \quad \text { for all } i, j, r
\end{aligned}
$$

In this study we employed output oriented CRS DEA model. Data on 81 countries over the time period of 2002 through 2012 are used for the empirical analysis. Our country selection process depends on data availability in World Bank. The inputs and output variables are as follows:

Output: Value added: Produced add value in agricultural area as USD currency, (constant 2005 US \$) 
Inputs: Agricultural land: It is estimated by the arable land used for farming, forestry, and production activities. It is measured in $\mathrm{km}$ square.

Fertilizers: It refers to the sum of pure weight of nitrogen, phosphate, potash, and complex fertilizers which were used for agriculture. It is measured in tons.

Labor: Participants in the economically active population in agriculture, i.e. employment in agriculture as a percentage of total employment.

In the second stage the relations between efficiencies of countries obtained by DEA and their governance indicators are analyzed by panel data analysis. For this stage The World Bank's Worldwide Governance Indicators (WGI) are used. The WGI rank countries with respect to six aspects of good governance: Voice and Accountability, Political Stability and Violence, Government Effectiveness, Rule of Law, Regulatory Quality, and Control of Corruption. These Indicators are defined as follows:

Voice and accountability: captures perceptions of the extent to which a country's citizens are able to participate in electing their government, freedom of expression, freedom of association, and a free media.

Political stability and the absence of violence measures the perception of the likelihood that the government will be abused or overthrown by violent or unconstitutional means, including domestic violence and terrorism.

Government effectiveness: perceives the quality of public services, the quality of civil service and the degree of independence from political repression, the quality of policy making and implementation, and the credibility of government's commitment to such policies.

Regulatory quality: captures perceptions of the ability of the government to formulate and implement sound policies and regulations that permit and promote private sector development.

Rule of law: perceptions of the extent to which agencies trust in the rules of society and the quality of contract enforcement, property rights, the courts and the police, and the possibility of crime and violence.

Control of corruption: the perceptions of the extent to which public power is exercised for private benefit, including both small and large forms of corruption, as well as capture of the state by elites and private interests

\section{Results}

The sample of the study includes 81 countries for the period of 2002-2012. Data were collected from World Bank data base. According to World Bank classification the sample consists of 34 high incomes, 27 upper-middle incomes, and 20 lower-middle and low incomes countries. Table1 displays the descriptive measurements of the groups of countries for 11 years from 2002 to 2012. All governance indicators of developed countries are higher than developing and undeveloped countries on average. Undeveloped countries have the worst governance compared to the other two groups. The differences between governance indices of groups are statistically significant at 0.001 level.

The changes of the efficiencies and the value added (in $\log$ ) produced by the 3 groups of countries on average during the study period 2002-2012 are shown on Graph 1 (also table 1). Undeveloped countries have the least agricultural value added on average for all the study period while developing countries have the highest value added. Value added is increasing during the time period in all types of countries. When the efficiencies of the groups obtained by DEA are compared it is seen that developed countries on average are the most efficient group for all the study period. The mean efficiency of this group is 0.445 . There is no statistically significant difference between mean efficiencies of developing (0.174) and undeveloped (0.197) countries. While efficiency in developed countries has an increasing trend undeveloped and developing have not.

Table 2 displays the pairwise correlations of governance indicators. It shows severe positive correlations between governance indicators. All the correlations are statistically significant at $1 \%$ level of significance. The fact is that if one of the indicators is good of a country means that the others are also good or if one of them is bad the others are also bad.

To analyze the effects of good governance on agricultural efficiency we apply panel data analysis. But severe multicollinearity between governance indicators may cause serious estimation problems if all indicators are used in the same model. Table 3 gives the pooled panel regression results of the 6 governance indicators one by one. A quadratic form was the best fitting model with positive coefficients for all the six indicators. This means that the marginal effects of governance indicators on efficiency are increasing in high values.

To compare the governance indicators in terms of the relations with efficiency, a two dimensional Euclidean distance plot of governance indicators and efficiency is also given on the Figure 1. Euclidean distance plot is used in Multidimensional scaling (MDS) analysis to provide a visual representation of the pattern of proximities (i.e., similarities or distances) among a set of objects. In our case the similarities or distances between efficiency and governance indicators are drawn. According to Euclidean distance plot corruption is farthest indicator to efficiency and then voice and accountability, rule of law, governance effectiveness, regulatory quality, and political stability and violence come in order. This means that the least efficient countries are the highest corrupted countries.

Because of multicollinearity between governance indicators the coefficients will not be efficient and unbiased in a regression model. That's why we applied exploratory factor analysis with varimax rotation which gives independent factors to the governance indicators to get the underlying factor structures. We got one factor explaining $86.26 \%$ of total variance $(\mathrm{KMO}=0.89$, significant at less than $1 \%$ ). We named this factor as "governance" which is the cumulative measurement of all the six governance indicators. 
Table 1 Descriptive statistics of countries

\begin{tabular}{|c|c|c|c|c|c|c|c|c|c|}
\hline & & Mean & Min & Max & & & Mean & Min & Max \\
\hline & UNV & -0.437 & -1.560 & 0.337 & & UNV & $7.07 \mathrm{E}+09$ & $3.33 \mathrm{E}+08$ & $4.85 \mathrm{E}+10$ \\
\hline Voice and & $\mathrm{DEV}$ & -0.143 & -1.872 & 1.157 & Value & $\mathrm{DEV}$ & $2.02 \mathrm{E}+10$ & $2.79 \mathrm{E}+08$ & $3.72 \mathrm{E}+11$ \\
\hline \multirow[t]{2}{*}{ Accountability } & DVD & 1.003 & -1.862 & 1.826 & \multirow[t]{2}{*}{ Added } & DVD & $1.46 \mathrm{E}+10$ & $6.20 \mathrm{E}+07$ & $1.48 \mathrm{E}+11$ \\
\hline & $\mathrm{T}$ & 0.266 & -1.872 & 1.826 & & $\mathrm{~T}$ & $1.46 \mathrm{E}+10$ & $6.20 \mathrm{E}+07$ & $3.72 \mathrm{E}+11$ \\
\hline \multirow{4}{*}{$\begin{array}{l}\text { Political } \\
\text { Stability and } \\
\text { Violance }\end{array}$} & UNV & -0.645 & -2.812 & 1.113 & \multirow{4}{*}{ Efficiency } & UNV & 0.197 & 0.004 & 1.000 \\
\hline & DEV & -0.289 & -2.390 & 1.180 & & DEV & 0.174 & 0.003 & 1.000 \\
\hline & DVD & 0.739 & -1.462 & 1.665 & & DVD & 0.445 & 0.005 & 1.000 \\
\hline & $\mathrm{T}$ & 0.055 & -2.812 & 1.665 & & $\mathrm{~T}$ & 0.294 & 0.003 & 1.000 \\
\hline \multirow{4}{*}{$\begin{array}{l}\text { Government } \\
\text { Effectivenes }\end{array}$} & UNV & -0.443 & -1.086 & 0.565 & \multirow{4}{*}{$\begin{array}{l}\text { Agricultural } \\
\text { land }\end{array}$} & UNV & $1.98 \mathrm{E}+05$ & $1.39 \mathrm{E}+04$ & $1.30 \mathrm{E}+06$ \\
\hline & $\mathrm{DEV}$ & -0.028 & -1.189 & 1.247 & & DEV & $5.92 \mathrm{E}+05$ & $8.70 \mathrm{E}+02$ & $5.27 \mathrm{E}+06$ \\
\hline & DVD & 1.228 & -0.459 & 2.430 & & DVD & $4.21 \mathrm{E}+05$ & $7.00 \mathrm{E}+00$ & $4.47 \mathrm{E}+06$ \\
\hline & $\mathrm{T}$ & 0.397 & -1.189 & 2.430 & & $\mathrm{~T}$ & $4.23 \mathrm{E}+05$ & $7.00 \mathrm{E}+00$ & $5.27 \mathrm{E}+06$ \\
\hline \multirow{4}{*}{$\begin{array}{l}\text { Regulatory } \\
\text { Quality }\end{array}$} & UNV & -0.286 & -0.964 & 0.677 & \multirow{4}{*}{ Fertilizer } & UNV & $7.13 \mathrm{E}+05$ & $3.66 \mathrm{E}+03$ & $4.66 \mathrm{E}+06$ \\
\hline & $\mathrm{DEV}$ & 0.000 & -1.692 & 1.310 & & DEV & $2.96 \mathrm{E}+06$ & $4.52 \mathrm{E}+03$ & $6.86 \mathrm{E}+07$ \\
\hline & DVD & 1.186 & -0.411 & 1.967 & & DVD & $1.25 \mathrm{E}+06$ & $3.88 \mathrm{E}+02$ & $2.07 \mathrm{E}+07$ \\
\hline & $\mathrm{T}$ & 0.427 & -1.692 & 1.967 & & $\mathrm{~T}$ & $1.69 \mathrm{E}+06$ & $3.88 \mathrm{E}+02$ & $6.86 \mathrm{E}+07$ \\
\hline \multirow{4}{*}{ Rule of Law } & UNV & -0.595 & -1.366 & 0.324 & \multirow{4}{*}{ Employment } & UNV & 37.858 & 15.600 & 71.600 \\
\hline & $\mathrm{DEV}$ & -0.269 & -1.686 & 1.057 & & DEV & 19.050 & 0.600 & 50.000 \\
\hline & DVD & 1.153 & -0.949 & 2.000 & & DVD & 5.801 & 0.800 & 19.300 \\
\hline & $\mathrm{T}$ & 0.248 & -1.686 & 2.000 & & $\mathrm{~T}$ & 18.133 & 0.600 & 71.600 \\
\hline \multirow{4}{*}{$\begin{array}{l}\text { Control of } \\
\text { Corruption }\end{array}$} & UNV & -0.661 & -1.445 & 0.253 & \multirow{4}{*}{$\begin{array}{l}\text { Number of } \\
\text { Countries }\end{array}$} & UNV & \multicolumn{3}{|c|}{$20(220$ obs $)$} \\
\hline & $\mathrm{DEV}$ & -0.233 & -1.241 & 0.706 & & DEV & \multicolumn{3}{|c|}{27 (297 obs) } \\
\hline & DVD & 1.176 & -1.088 & 2.553 & & DVD & \multicolumn{3}{|c|}{34 (374 obs) } \\
\hline & $\mathrm{T}$ & 0.253 & -1.445 & 2.553 & & $\mathrm{~T}$ & \multicolumn{3}{|c|}{81 (891 obs) } \\
\hline
\end{tabular}

UNV: Undeveloped, DEV: Developing, DVD: Developed, T: Total

Table 2 Correlations between governance indicators

\begin{tabular}{|c|c|c|c|c|c|c|}
\hline & $\mathrm{va}$ & psv & ge & $\mathrm{rq}$ & $\mathrm{rl}$ & $\mathrm{cc}$ \\
\hline va & 1 & & & & & \\
\hline psv & $0.701 * *$ & 1 & & & & \\
\hline ge & $0.781 * *$ & $0.756^{* *}$ & 1 & & & \\
\hline $\mathrm{rq}$ & $0.832 * *$ & $0.728 * *$ & $0.923 * *$ & 1 & & \\
\hline $\mathrm{rl}$ & $0.793 * *$ & $0.786 * *$ & $0.959 * *$ & $0.923 * *$ & 1 & \\
\hline $\mathrm{cc}$ & $0.775 * *$ & $0.760 * *$ & $0.949 * *$ & $0.872 * *$ & $0.947 * *$ & 1 \\
\hline
\end{tabular}

**. Correlation is significant at the 0.01 level (2-tailed)., va: voice and accountability, psv: political stability and violance, ge: governance effectivenes, rq: regulatory quality, rl: rule of law, cc: control of corruption

Table 3 Regression analysis of governance indicators on efficiency

\begin{tabular}{|c|c|c|c|c|c|c|c|}
\hline & B & $\mathrm{t}$ & sig & & $\mathrm{B}$ & $\mathrm{t}$ & sig \\
\hline $\begin{array}{l}\text { costant } \\
\text { va } \\
\text { vasquare }\end{array}$ & $\begin{array}{l}0.198 \\
0.090 \\
0.079 \\
F=93.7 \\
\end{array}$ & $\begin{array}{l}15.379 \\
8.895 \\
7.490 \\
P=0.000\end{array}$ & $\begin{array}{l}0.000 \\
0.000 \\
0.000 \\
\text { Rsq }=0.174\end{array}$ & $\begin{array}{l}\text { costant } \\
\text { rq } \\
\text { rqsquare }\end{array}$ & $\begin{array}{l}0.195 \\
0.094 \\
0.066 \\
F=117.7\end{array}$ & $\begin{array}{l}16.949 \\
6.592 \\
5.704 \\
P=0,000\end{array}$ & $\begin{array}{l}0.000 \\
0.000 \\
0.000 \\
\text { Rsq }=0.209\end{array}$ \\
\hline $\begin{array}{l}\text { costant } \\
\text { psv } \\
\text { psvsquare }\end{array}$ & $\begin{array}{l}0.231 \\
0.158 \\
0.071 \\
F=126.3\end{array}$ & $\begin{array}{l}20.109 \\
15.421 \\
7.323 \\
\mathrm{P}=0.000\end{array}$ & $\begin{array}{l}0.000 \\
0.000 \\
0.000 \\
\text { Rsq }=0.221\end{array}$ & $\begin{array}{l}\text { costant } \\
\text { rl } \\
\text { rlsquare }\end{array}$ & $\begin{array}{l}0.201 \\
0.091 \\
0.069 \\
F=175.6\end{array}$ & $\begin{array}{l}16.881 \\
7.607 \\
6.834 \\
P=0,000\end{array}$ & $\begin{array}{l}0.000 \\
0.000 \\
0.000 \\
\text { Rsq }=0.283\end{array}$ \\
\hline $\begin{array}{l}\text { costant } \\
\text { ge } \\
\text { gesquare }\end{array}$ & $\begin{array}{l}0.190 \\
0.063 \\
0.079 \\
F=175.5\end{array}$ & $\begin{array}{l}17.853 \\
3.962 \\
7.255 \\
P=0.000\end{array}$ & $\begin{array}{l}0.000 \\
0.000 \\
0.000 \\
\text { Rsq }=0.283\end{array}$ & $\begin{array}{l}\text { costant } \\
\text { cc } \\
\text { ccsquare }\end{array}$ & $\begin{array}{l}0.223 \\
0.080 \\
0.044 \\
F=149.1\end{array}$ & $\begin{array}{l}19.727 \\
5.948 \\
5.093 \\
\mathrm{P}=0,000\end{array}$ & $\begin{array}{l}0.000 \\
0.000 \\
0.000 \\
\text { Rsq }=0.251\end{array}$ \\
\hline
\end{tabular}

Dependent variable: efficiency, Independent variables: va: voice and accountability, psv: political stability and violance, ge: governance effectivenes, rq: regulatory quality, rl: rule of law, cc: control of corruption 

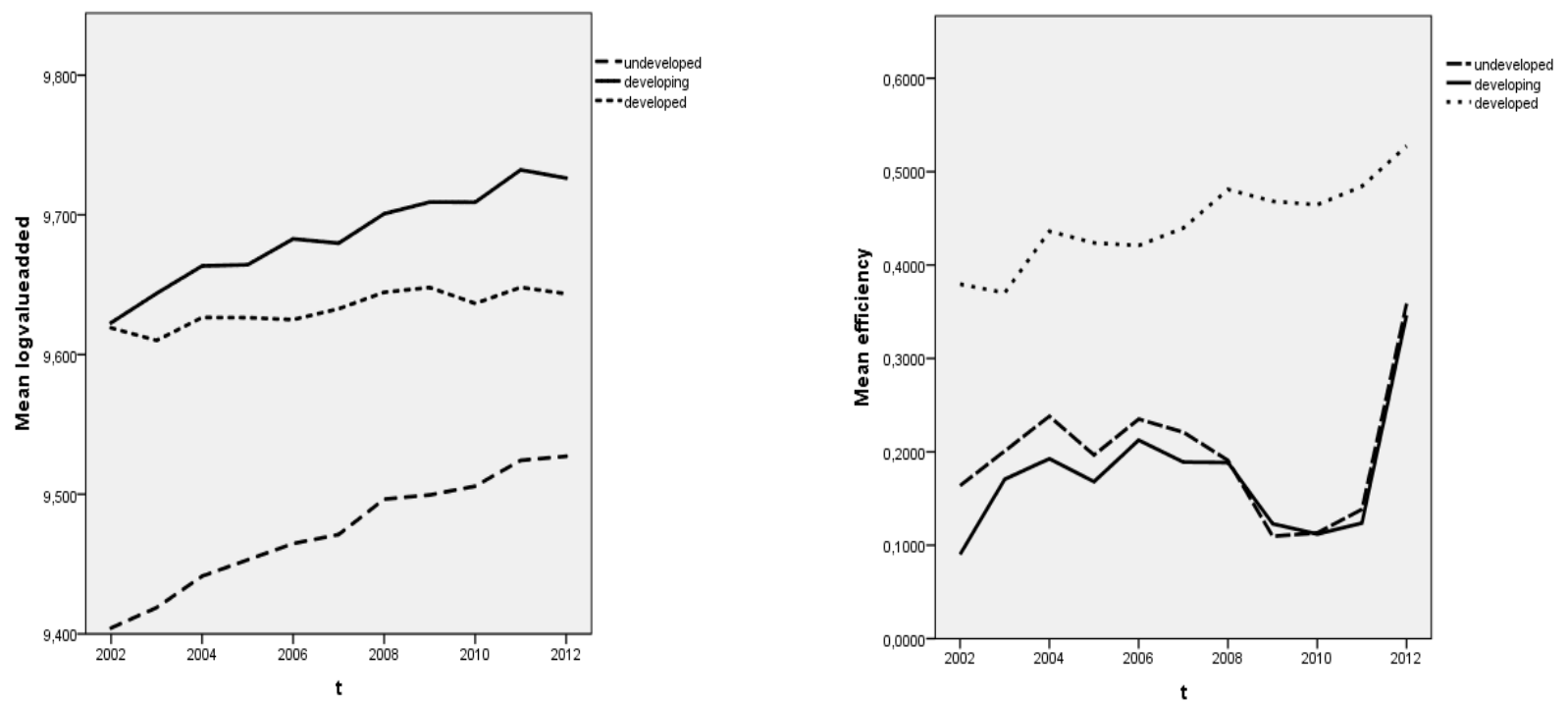

Graph 1 The Changes in Efficiency and Value Added in Developing, Developed and Undeveloped Countries (2002 - 2012)

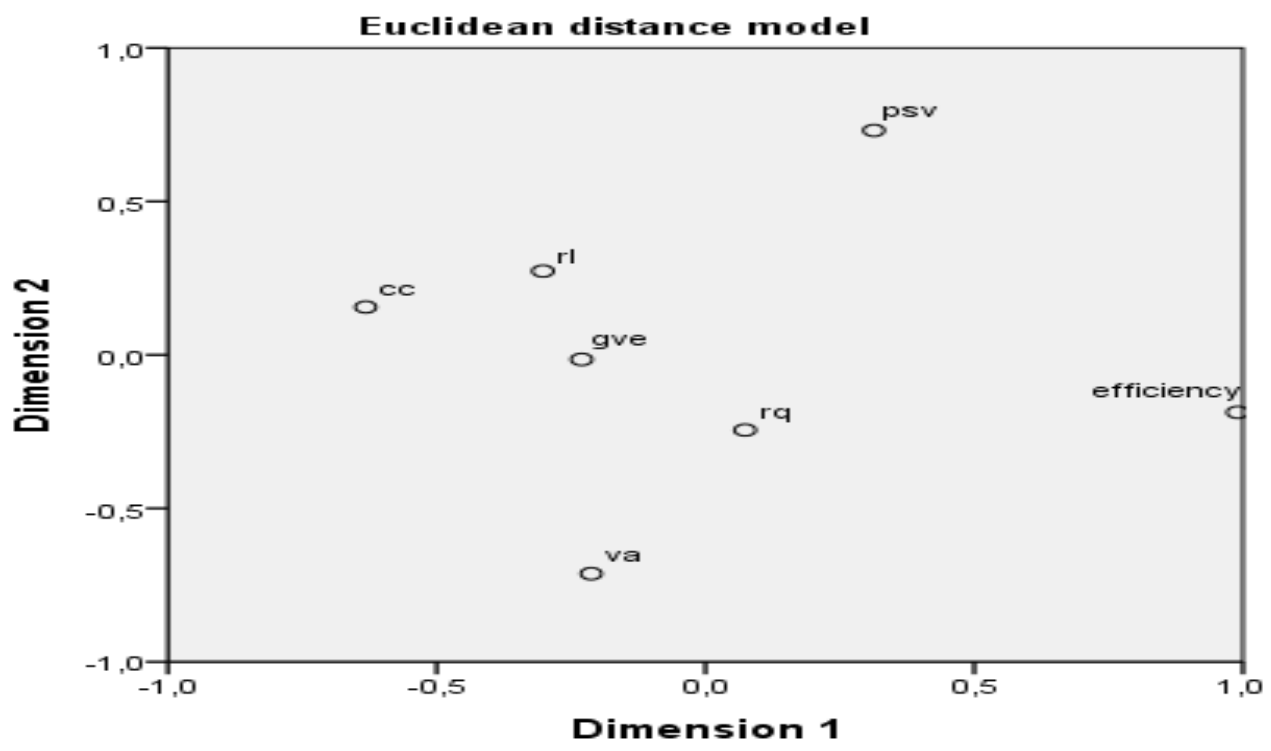

Figure 1 A Two Dimensional Euclidean Distance Plot of Indicators and Efficiency

va: voice and accountability, psv: political stability and violance, ge: governance effectivenes, rq: regulatory quality, rl: rule of law, cc: control of corruption

Table 4 Regression analysis of the factor of governance and efficiency

\begin{tabular}{l|ccc}
\hline & $\mathrm{B}$ & $\mathrm{t}$ & $\mathrm{sig}$ \\
\hline constant & 0.277 & 12.852 & 0.000 \\
undeveloped & -0.047 & -1.362 & 0.174 \\
developing & -0.088 & -3.084 & 0.002 \\
governance & 0.094 & 6.368 & 0.000 \\
governance^2 & 0.057 & 5.686 & 0.000 \\
& $\mathrm{~F}=82.86$ & $\mathrm{P}=0.000$ & $\mathrm{R}-\mathrm{sq}=0.272$ \\
& $\mathrm{~N}=891$ & & (81 countries) \\
\hline
\end{tabular}

Dependent variable; efficiency, governance; combination of 6 governance indicators obtained by Exploratory Factor Analysis. governance^2; the square of governance, undeveloped: under developed countries, developing: developing countries, developed countries are base dummy 
We analyzed the effects of this factor "governance" on efficiency. Type of country is added into the model as dummy variable (developed is base dummy). The results are given in Table 4. Both governance and the square of governance are again significant $(\mathrm{P}<0.001 \%)$ with positive coefficients. That is the marginal effect of governance is increasing in high values of governance when types of countries are kept constant. The coefficients of country types are both negative when governance is kept constant. The difference between efficiencies of developing and developed countries is significant. Developed countries are more efficient than the developing countries even the governance was kept constant. The efficiency difference is $8.8 \%$ on average. But while developed countries are $4.7 \%$ more efficient than undeveloped countries on average, the difference was not statistically significant if governance is constant. The differences between efficiencies while governance is constant can be explained as the effects of technological devices, materials, and production styles.

\section{Conclusion and Discussion}

Agriculture is of priority for economic development. There is a positive relationship between development and agriculture. In this respect, the technology and applied policies for development in agricultural industry are as important as land.

In this study, the efficiencies of 81 countries in agriculture were comparatively analyzed. Firstly, Data Envelopment Analysis (DEA) was utilized for finding the efficiencies of countries' agriculture industries. Produced add value in agricultural area was the output while the inputs are agricultural land, fertilizers, and labor. DEA results showed that developed countries on average are the more efficient for all the study period than developing and undeveloped countries. There is no statistically significant difference between mean efficiencies of developing and undeveloped countries. While efficiency in developed countries has an increasing trend between 2002 and 2012 undeveloped and developing have not. Secondly, panel regression analysis was employed in order to examine the relations between countries' agricultural efficiencies and countries' good governance implementations namely; voice and accountability, government effectiveness, regulatory quality, control of corruption, political stability and violence, and rule of law. Results displayed that firstly, there are high positive correlations between governance indicators. Secondly, pooled panel regression analyses of the 6 governance indicators gave a quadratic form as the best fitting model with positive coefficients. This means that the marginal effects of governance indicators on efficiency are increasing in high values. Thirdly, according to Euclidean distance plot corruption is the farthest indicator to efficiency. This means that the least efficient countries are the highest corrupted countries. Fourthly, the six governance indicators constructed one factor (named governance) extracting $86.26 \%$ of total variance. When this factor regressed on efficiency, the governance variable and its square found to have significant $(\mathrm{P}<0.001 \%)$ effects on efficiency with positive coefficients. That is the marginal effect of governance is increasing in high values of governance when types of countries are kept constant. Fifthly, developed countries are more efficient than the developing countries even the governance was kept constant. But, even developed countries are $4.7 \%$ more efficient than undeveloped countries on average; the difference was not statistically significant if governance was kept constant. The differences between efficiencies of developed countries and others while governance is constant might show the effects of technological production styles, devices and materials on efficiency.

Farmers cannot market their products if an agricultural industry of a country is traditional and not perfectly competitive. The prices are not determined under perfect competition conditions and the intermediaries use the situation. Harvey (2004) argued that the three main factors increased the political pressure on government interventions and protection on the agricultural industry.

The first is the law of Engel; with the economic progress, the relative significance of agriculture is decreasing and the political pressure of protection is increasing (De Gorter and Tsur, 1991). The second is that agricultural products are indispensable for survival and prosperity. Finally, because of the separable nature of the agricultural industry, producers earn more from political manipulation when compared to market competition.

Stigler (1951) combines the ability to discover modern farming methods and development with a network of extensive change that supports the use of inputs such as machinery, chemical fertilizers and division of labor. It is emphasized that the realization of these factors requires specialists to ensure the development and sustainability of specialized inputs. For such a large and complex network of change, it is not enough to make progress through tradition, culture and social oppression. For change, there is a need for a fair constitutional system that forms the basis of a law of contracts and a democratic society.

The concept of governance, which provides the institutions necessary for effective development, has an important influence on the productivity of an agricultural production of a country. Weak institutions and policies alleviate the adaptation of appropriate technologies as well as the influence of organized innovations (Hayami and Rutan, 1985). In the 2008 World Development Report (World Bank 2008), it has been argued that governance forms the basis of agricultural development and that processes such as democratization, civil society participation, public administration reforms and control of corruption have great potential for the development of agriculture.

\section{References}

Azmat F, Coghill K. 2005. Good governance and marketbasedreforms: a study of Bangladesh. International Review of Administrative Sciences, 71: 625-638. 
Bayyurt N, Yilmaz S. 2012. The impacts of governance andeducation on agricultural efficiency: an international analysis. Procedia - Social and Behavioral Sciences, 58: 1158 1165 .

Bayyurt N, Serin ZV, Arıkan FE. 2015. Good Governance and Agricultural Efficiency, Journal of Social and Development Sciences Vol. 6, No. 1, March, pp. 14-23.

Beckmann V, Boger S. 2003. Courts and contract enforcement intransition agriculture: theory and evidence from Poland Proceedings of the 25th International Conference of Agricultural Economists.

Boland M. 2009. What is Value-added Agriculture? AgriculturalMarketing Resource Center. Available at http://www.agmrc.org/business_development/getting_prepared/ valueadded_agriculture/articles/

Campos JE, Lien D, Pradhan S. 1999. "The Impact of Corruptionon Investment: Predictability Matters", World Development, Vol.27, Issue:6, pp.1059-1067

Charnes A, Cooper WW, Rhodes E. 1978. Measuring theefficiency of decision making units. European journal of operational research, 2(6): 429-444.

Charnes, A, Cooper WW, Lewin AY, Seiford LM. 1994. Data Envelopment Analysis: Theory, Methodology, and Applications.

Çakmak E, Dudu H, Öcal N. 2008. Efficiency in TurkishAgriculture and a Quantitative Analysis (Turkish), Ankara: TEPAV

De Gorter H, Tsur Y. 1991. Explaining Price Policy Bias InAgriculture: The Calculus of Support-Maximising Politicians. American Journal of Agricultural Economics, 73(4): 1244 1254.

Deliktaş E, Ersungur SM, Candemir M. 2005. The comparasion of agricultural efficiency and productivity growth in the EU and Turkey, 1980-2002. International Journal of Business, Management and Economics, 1, pp.109-124

Feng Y. 2003. Democracy, Governance and EconomicPerformance: Theory and Evidence, Cambridge: MA, MIT Press.

Fuglie KO, Wang SL. 2013. New evidence points to robust butuneven productivity growth in global agriculture. Global Journal of Emerging Market Economies, 5(1): 23-30.

Ghalambaz F, Moghaddasi R, Moohammadinejad A. 2015 Theimpact of good governance indicators on agricultural efficiency of developing countries. MAGNT Research Report (ISSN,144-8939), 3(2): 12-20.

Globerman S, Shapiro D, Tang Y. 2006. Foreign directinvestment in emerging and transition European countries. Center for International Business, Western Washington University

Graham J, Amos B, Plumptre T. 2003. Principles for goodgovernance in the 21st century. Policy brief, 15: 1-6.

Harvey DR. 2004. Policy Dependency and Reform: EconomicGains versus Political Pains. Agricultural Economics, 31, 265-275.

Hayami Y, Ruttan V. 1985. Agricultural Development: AnInternational Perspective. Baltimore, MD: Johns Hopkins University Press.

IFAD. 1999. International Fund for Agricultural Development Good Governance: An Overview, International Fund for Agricultural Development, Executive Board - Sixty-Seventh Session Rome, 8-9 September

IFPRI. 2014. International Food Policy Research Institute. Governance for Agricultural and Rural Development Program, Available at http://www.ifpri.org/sites/default/files/ govbrochure_1.pdf,[11.1.2014]

Kaufmann D, Kraay A, Mastruzzi M. 2006a. Governance mattersIII: Governance indicators for 1996-2005. World Bank Policy Research Working Paper, WPS 3106. Washington, D.C, World Bank.

Kaufmann D, Kraay A, Mastruzzi M. 2006b. Governancematters V: Aggregate and individual governance indicators for 1996-2005. World Bank Policy Research Working Paper, WPS 4012, Washington, D.C.: World Bank.
Kaufmann D, Kraay A. 2008. Governance indicators: Where arewe, where should we be going? The World Bank Research Observer, 23(1): 1-30.

Kaya A, Avc1 MA. 2008. 'Efficiency and Total FactorAnalysis in Trasition Economies and Turkish Agricultur 1992-2004', (Turkish) Ege Academic Review,Vol. 8, pp. 843-860

Knack SF. 2003. Democracy, governance, and growth.Michigan: University of Michigan Press.

Keefer P, Knack S. 1997. Why Don't Poor Countries Catch Up? ACross-National Test of an Institutional Explanation. Economic Inquiry, 35(3): 590-602.

Lio M, Liu MC. 2008. Governance and agricultural productivity:a cross-national analysis. Food Policy, 33(6): 504-512.

Malhotra C, Chariar VM, Das LK, Ilavarasan PV. 2007. ICT for Rural Development: An Inclusive Framework for eGovernance. Computer Society of India, 216-226.

Massuanganhe I. 2008. Policies, Natural Resource GovernanceAnd Local Development In Mozambique. Phd dissertation, University of Free State, Bloemfontein. Available at http://ageconsearch.umn.edu/bitstream/53061/2/Thesis_PhD_v 5_Final_Published.pdf.

Meidari A, 2004. Change in World Banks policies and theemergence of the theory of good governance. Journal of Economy, 10: 93-118.

Méon P, Weill L. 2005. Does better governance fosterefficiency? An aggregate frontier analysis. Economics of Governance, 6(1): 75- 90 .

Minh NK, Long GT. 2008. Measuring agricultural productionefficiency in Vietnam: An application of data envelopment analysis. Working Paper 0813, Vietnam Development Forum.

Niyongabo G. 2003. Trade openness policy, quality of institutionsand economic growth. University Auvergne, Clermont Ferrand, France. MAGNT Research Report (ISSN. 1444-8939), 3(2): 12-20.

Nguyen KM, Giang TL 2009. Measuring Agricultural Production Efficiency in Vietnam: An Application of Data Envelopment Analysis, Agricultural Economics Review, Vol 10, No 2.

Ogundari K, Amos TT, Okoruwa VO. 2012. A review ofNigerian agricultural efficiency literature, 1999-2011: What does one learn from frontier studies?. African Development Review, 24(1): 93-106.

Olson M. 1996. Distinguished lecture economics in government big bills left on the sidewalk: Why some nations are rich, and others poor. Journal of Economic Perspectives, 10(2): 3-24

Otsuka K. 2013. Food security, income inequality and the changing comparative advantage in world agriculture. Agricultural Economics, 44: 1-12.

Pender J, Fafchamps M. 2001. Land lease markets and agriculturalefficiency: Theory and evidence from Ethiopia. Environment and Production Technology Division, International Food Policy Research Institute. Available athttp://www.ifpri.org/sites/default/files/publications/eptdp81.p df

Rivera-Batiz FL. 2002. Democracy, governance, and economicgrowth: Theory and evidence. Review of Development Economics, 6(2): 225-247.

Serrao A. 2003. Agricultural productivity analysis of EuropeanUnion and eastern regions. In presentation at the American Agricultural Economics Association Annual Meeting. Canada.

Siudek T, Zawojska A. 2014. Quality of national governance andrural development: The case of the European Union countries. EAAE 2014 Congress "Agri-Food and Rural Innovations for Healthier Societies”, Ljubljana, Slovenia,

Stigler J. 1951. The Division of Labor is limited by the Extent ofthe Market. Journal of Political Economy, 59, 185-194 